\title{
Syncretism in Dutch dialects
}

\author{
Suzanne Aalberse $\cdot$ Jan Don
}

Received: 15 April 2008 / Accepted: 20 March 2009 / Published online: 10 July 2009

(C) The Author(s). This article is published with open access at Springerlink.com

\begin{abstract}
Dutch dialects show an enormous amount of variation with respect to the verbal inflectional paradigm. To wit, some dialects only have two forms in the present tense indicative to express all persons in singular and plural, whereas other dialects use three or even four different forms to do so. However, not every inflectional pattern is equally likely to occur; some patterns are found nowhere, whereas others are geographically widespread and stable over time. We will show that these recurring patterns of syncretism are also typologically well-attested. The recurring pattern involves neutralization of a morphosyntactic distinction in the marked half of the paradigm. More specifically, we see that plural and past tense are neutralizing contexts. We will show that a grammar that solely uses underspecification of affixes to account for the observed syncretisms, misses a generalization that can only be expressed by impoverishment rules or some other equivalent paradigmatic means.
\end{abstract}

Keywords Verbal inflection - Syncretism - Morphological neutralization · Dialectal variation · Impoverishment · Person marking · Number marking

\section{Introduction}

Dutch dialects show an enormous amount of variation with respect to the verbal inflectional paradigm. To wit, some dialects only have two forms in the present tense indicative to express all persons in singular and plural, whereas other dialects use three or even four different forms to do so. However, despite the variation, it is clear that not every inflectional pattern is equally likely to occur; there are logically possible patterns that are found nowhere, whereas other patterns are geographically

S. Aalberse · J. Don $(\bowtie)$

Universiteit van Amsterdam, Amsterdam, The Netherlands

e-mail: j.don@uva.nl 
widespread and stable over time. We will show that there are recurring patterns of syncretism that are also typologically well-attested. (cf. Cysouw 2005; Baerman et al. 2005). The patterns that we describe below as stable in most of the dialectal variants, are also typologically very common. The recurring pattern involves neutralization of a morphosyntactic distinction in the marked half of the paradigm (Bobaljik 2008). More specifically, we see that plural and past tense are neutralizing contexts (Aikhenvald and Dixon 1998, p. 66; Baerman et al. 2005, pp. 59, 200).

Recently, Bennis and MacLean (2006) have tried to explain the variation in Dutch verbal inflection, and the limits thereof, in terms of a general economy principle that minimizes the amount of featural information per affix. We will argue that this purely affix-based approach suffers from two problems. First, it does not explain why certain syncretisms are more common than others; whereas our approach makes clear that it is in the marked section of the paradigms that neutralization takes place. Second, we will show that despite the wide geographical variation in the Dutch inflectional system, some patterns are quite stable across the area. These stable patterns are independent of the affixes used and therefore, cannot be expressed by means of affixal underspecification as proposed by Bennis and MacLean (2006). For example, in Standard Dutch, person marking is absent in the past tense. We will argue that this cannot be a property (lack of person marking) of the past tense suffix, but is a more general 'paradigmatic' property of Dutch. Therefore, we will argue that an analysis that only makes use of underspecification of affixal information cannot properly describe the rather stable patterns found amidst the variation in the Dutch inflectional landscape. Within Distributed Morphology (Halle and Marantz 1993; Halle 1997) such paradigmatic structure would be expressed as an Impoverishment Rule, whereas in paradigmatic approaches (e.g. Stump 2001; Wunderlich 1997) it would be a case of paradigmatic neutralization. We do not take any particular theoretical position with respect to this issue in this paper, ${ }^{1}$ but simply use the Impoverishment rules as a descriptive device to express the relevant neutralization patterns.

\section{2 'Meta-paradigmatic' structure and impoverishment rules}

Williams (1994) [see also Baerman (2000), and Bobaljik (2003) for discussion] argues that languages seem to display 'meta-paradigmatic' structure; i.e. separate from the individual morphemes, and across different paradigms, the same pattern may recur. To give an example, have a look at the following Dutch data:

$$
\begin{aligned}
& \text { a. de jongen 'the boy' } \\
& \text { plur.: de jongen-s } \\
& \text { b. deze jongen 'this boy' } \\
& \text { plur.: deze jongen-s 'these boys' } \\
& \text { c. } \\
& \text { die jongen 'that boy' } \\
& \text { plur.: die jongen-s 'those boys' }
\end{aligned}
$$

het kind 'the child' de kind-eren 'the children' dit kind 'this child' deze kind-eren 'these children' dat kind 'that child' die kind-eren 'those children'

\footnotetext{
1 See for discussion about whether or not to use paradigms as a theoretical notion, Williams (1994), Bobaljik (2003), and also Wunderlich (1997).
} 
d. een mooi-e jongen

een mooi kind 'a beautiful child'

'a beautiful boy'

plur.: mooi-e jongen-s

mooi-e kind-eren 'beautiful children'

In the left-hand column in (1) we see that nouns with common gender in Dutch show the same choice of demonstrative and adjectival inflection in the singular and in the plural. However, in the right-hand column we see that neutral nouns pattern differently in the plural and the singular. Moreover, we can see that the agreement in the noun phrases (i.e. the form of the demonstratives, the article, and the adjective) headed by the plural neuter nouns, exactly mirrors the agreement found in the noun phrases headed by common nouns. This could be easily expressed by assuming that there is neutralization of gender in the plural. As a descriptive device to account for such neutralization, we could assume a rule such as (2):

(2) $[$ neuter $] \rightarrow \varnothing /$ [plural]

Whether it is in the form of an impoverishment rule such as (2), or in any other way, the language user must have knowledge of the fact that neuter gender does not play a role in the plural. ${ }^{2}$

The inflectional pattern for regular verbs in Dutch (which is an open class and comprises $99 \%$ of the verbs in Dutch) is as follows. ${ }^{3}$

(3) Standard Dutch verbal inflection (regular verbs):

\begin{tabular}{lllll} 
& Present & \multicolumn{3}{l}{ Past } \\
& sing. & plur & sing. & Plur. \\
$1^{\text {st }}$ & $-\varnothing$ & -en & -te /-de & -ten /-den \\
$2^{\text {nd }}$ & -t & -en & -te /-de & -ten /-den \\
$3^{\text {rd }}$ & -t & -en & -te /-de & -ten /-den
\end{tabular}

If -tel-de is combined with the plural suffix $-e n$, the form -ten/-den surfaces due to schwa-deletion (-te or -de +-en =-ten or -den). If we were to give a purely affix-based description of the syncretisms in this inflectional paradigm, allowing

\footnotetext{
${ }^{2}$ As an anonymous reviewer points out this is problematic in view of the fact that prenominal adjectives may be left without an inflectional schwa in certain more ore less fixed combinations, whereas non-neuter nouns may not lose this schwa (cf. Booij 2002, pp. 47-48):

(i) de controlerend- $\varnothing$ geneesheer 'the medical officer'

(ii) controlerend- $\varnothing$ geneesher-en 'medical officer-plur'

(iii) controlerend-e geneesher-en 'controlling doctors'

(iv) het oudheidkundig- $\varnothing$ museum 'the archeological museum'

(v) *oudheidkundig- $\varnothing$ museum-s

(vi) oudheidkundige museums 'archeological museum-plur.'

However, the data are not so clear-cut as suggested by Booij (2002). We have asked several native speakers and of those speakers that accept (i) more than half rejects (ii). For those speakers that accept (ii) and reject (v), the form with the schwa in (iii) has a purely compositional interpretation. So, for them (ii) and (iii) have different interpretations. There is however only a single interpretation for the forms in (v) and (vi). Maybe in order to avoid the compositional interpretation of the form in (iii), the form without schwa in (ii) is more acceptable.

${ }^{3}$ Spelled 'e' is [ə].
} 
ourselves underspecification of features, we would arrive at the description in (4) (see also Bennis and MacLean 2006, p. 298):

(4) Underspecification account:

$\begin{array}{lll}-\varnothing & \leftrightarrow & {[1]} \\ \text {-t } & \leftrightarrow & {[2 / 3]} \\ \text {-te /-de } & \leftrightarrow & \text { [past] } \\ \text {-en } & \leftrightarrow & \text { [plur] }\end{array}$

However, this description misses a generalization, which becomes clear once we take a look at the inflectional paradigm of irregular verbs:

(5) Dutch verbal inflection (irregular verbs):

$\begin{array}{lllll} & \text { Present } & & \text { Past } & \\ & \text { sing. } & \text { plur. } & \text { sing. } & \text { plur. } \\ 1^{\text {st }} & -\varnothing & \text {-en } & -\varnothing & \text {-en } \\ 2^{\text {nd }} & -\mathrm{t} & \text {-en } & -\varnothing & \text {-en } \\ 3^{\text {rd }} & -\mathrm{t} & \text {-en } & -\varnothing & \text {-en }\end{array}$

Although the past tense of these irregular verbs is not expressed by means of the affix -del-te, it still holds true that there is no person distinction in the past. Therefore, the underspecification of the past tense suffix -te /-de in (4) does not help us to cover this particular syncretism. Moreover, a similar pattern of syncretism is found in the highly irregular verb zijn 'to be'. Here, a completely different form expresses the past tense, but again this form is identical for all persons, as can be seen from (6):

(6) Standard Dutch zijn ('to be')

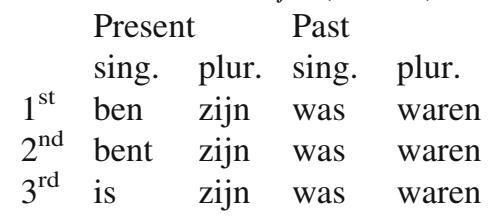

The conclusion is that the syncretisms in the plural and the past tense do not result from the underspecification of affixes, but is a property of the verbal inflectional paradigm of Dutch. In order to describe these syncretisms, we may make use of the following two 'Impoverishment' rules. ${ }^{4}$

(7) Impoverishment rules for Standard Dutch:

a. $\quad[\alpha$ person $] \rightarrow \varnothing /$ [plural $]$

b. $[\alpha$ person $] \rightarrow \varnothing /$ [past]

Below we will show that the despite the large amount of variation, Dutch dialects are remarkably constant with respect to the patterns expressed by the rules in (7). Again, this can not be a property of the affixes involved, but must result from some

\footnotetext{
${ }^{4}$ The term 'impoverishment' does not imply any judgment of whatever nature w.r.t to the language system; it is simply a term that adequately describes that some feature ([person] in the present case) is not marked in a particular morphosyntactic environment.
} 
grammatical means that expresses these patterns without reference to the individual affixes involved.

\section{Dialectal variation in Dutch}

The inflectional paradigms of many Dutch dialects have been recorded in a project often referred to as the GTR-project. ${ }^{5}$ These data are available through an electronic version of the Morphological Atlas of the Dutch Dialects (MAND), including no less than 613 measure points ${ }^{6}$ spread over the Netherlands, Belgium (Flanders) and the outermost Northern part of France (van den Berg 2003). The subjects were native speakers of the dialect that were between 50 and 75 years of age and preference was given to lower-educated people. Data were gathered through a questionnaire (about 1,900 items per questionnaire). We have investigated the full inflectional paradigm of the verb kloppen 'to knock'.

\subsection{Person marking in the plural}

If we take a look at the forms in present tense plural, we find that there is no person marking in $362(=59 \%)$ of the 613 dialects. To compare, 538 dialects $(=95 \%)$ of the dialects have person markings in the singular present tense. Apparently, the impoverishment rule here describes a pattern of syncretism that is indeed frequently attested in many Dutch dialects, although not in all variants.

Two groups of dialects do not conform to the generalization that person marking is absent in the plural. First, there is a relatively small group of dialects (20) spoken in the Eastern part of the Netherlands (see Map 1) that do not show the relevant syncretism.

This, however, is only an apparent exception. To see this, consider first the plural present tense of the verb kloppen in the dialect of Smilde:

$$
\begin{array}{lll}
\text { a. } & 1^{\text {st }} & \text { klop-m plural paradigm kloppen 'to knock' (Smilde) } \\
2^{\text {nd }} & \text { klop-t } \\
3^{\text {rd }} & \text { klop-t }
\end{array}
$$

From these data it seems that first person is marked with respect to the other two forms in the plural, which is not expected given the stability of the syncretic pattern. However, consider next the present plural paradigm from the same dialect of the verb leven 'to live':

$$
\begin{array}{ll}
\text { b. } 1^{\text {st }} & \text { leve-t plural paradigm leven 'to live' (Smilde) } \\
2^{\text {nd }} & \text { leve-t } \\
3^{\text {rd }} & \text { leve-n }
\end{array}
$$

\footnotetext{
5 This refers to the Goeman, Taeldeman and Van Reenen project, named after the three people responsible for this large collection of dialect data.

${ }^{6}$ It seems customary to use the term 'dialect' for each of these different measure-points. Strictly speaking, there may be (far) more than a single measure point per dialect. Nevertheless, we will stick to the customary use here.
} 


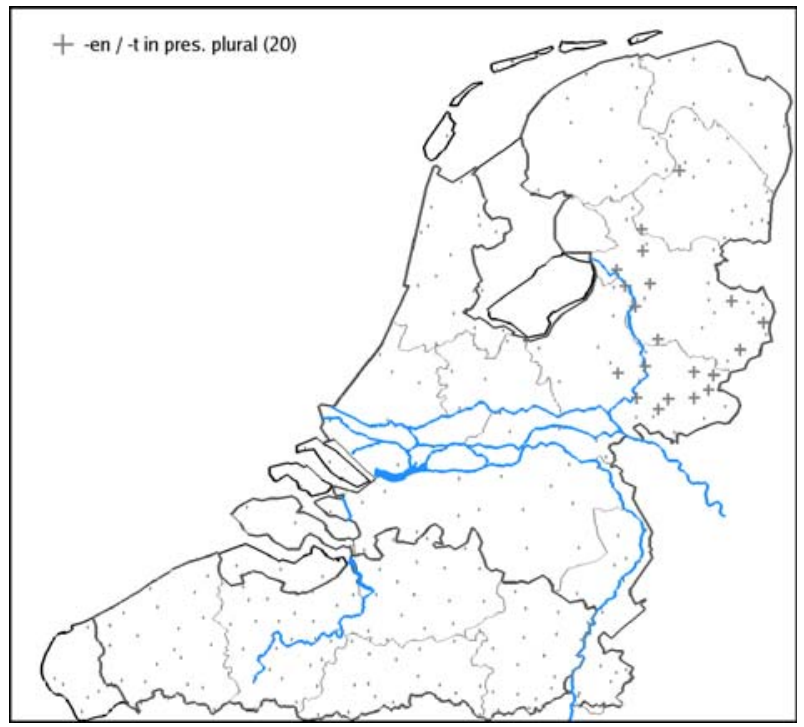

Map 1 Dialects with free variation between $-n$ and $-\mathrm{t}$ in present tense plural ${ }^{8}$

In this paradigm the nasal marks third person, distinguishing it from the $-t$ in first and second person. If we compare the same paradigms in these 20 dialects, we find that there is free variation between $-t$ and a nasal in the plural. So, the marking of person here is only apparent, but underlyingly the system adheres to the pattern expressed by rule (7a). ${ }^{7}$

A second, much larger group of dialects $(241=39 \%)$, does have a person marking in the present plural. A typical paradigm is the one of Nistelrode in (9):

(9) $1^{\text {st }}$ klop-e plural paradigm of kloppen 'to knock' (Nistelrode)

$2^{\text {nd }}$ klop-t

$3^{\text {rd }}$ klop-e

This pattern is found in the whole of Flanders and the South Eastern part of Dutch Brabant and Dutch Limburg (see Map 2).

We conclude that, as far as the plural present tense is concerned indeed the syncretic pattern is found in most dialects spoken in the Northern part of the Dutch speaking area.

\footnotetext{
${ }^{7}$ For more details see also Aalberse (2007).

${ }^{8}$ We gratefully acknowledge the electronic version of the 'Dynasand' (Barbiers et al. 2006). All maps showing the geographical distribution of the phenomena discussed, are made with the help of the Dynasand.
} 


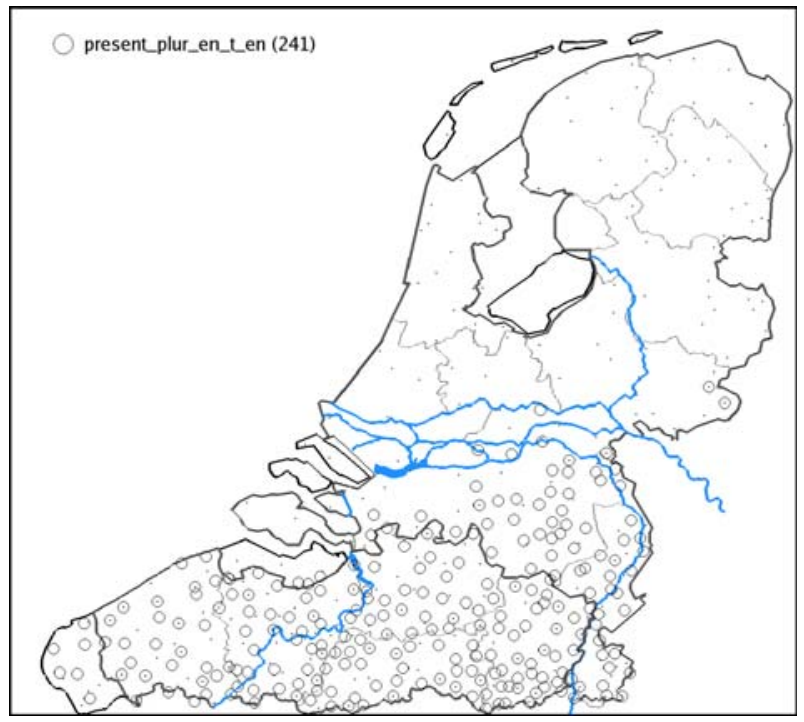

Map 2 Dialects with -t in second person plural present tense

\subsection{Person marking in the past tense singular}

In the singular of the past tense, $452(=74 \%)$ of the dialects show no person marking. So, the impoverishment rule in (7b) also describes a well-attested pattern. However, in the remaining $161(=26 \%)$ dialects, we do find person marking. The group of dialects with person markings (going against the syncretic pattern) falls apart in two: (a). dialects with retention of $d u$ 'you' as a second person pronoun $(136=22 \%)$, and (b). dialects with $-e n$ in the second person singular $(25=4 \%)$.

The first group of dialects (136 dialects) that show marking of person in the singular past tense, is characterized by the fact that they all show retention of the second person pronoun $d u$. A typical example is the dialect of Veendam:

$\begin{array}{lll}1^{\text {st }} & \text { klob-de past tense singular of kloppen 'to knock' (Veendam) } \\ 2^{\text {nd }} & \text { klob-de-st }\end{array}$

All these dialects show the ending -st, or a variant thereof, in the past. This ending is also found in the present tense (2nd person) in these dialects. It turns out that this personal pronoun is very tightly connected to its original (Middle Dutch) inflectional ending. Every dialect in Dutch that still has the pronoun $d u$ also has the ending -st in the singular present and past tense (see also Aalberse 2004). Map 3 illustrates this point.

Apparently the same factors that explain the retention of $d u$, explain the retention of the - st suffix. We refer to Aalberse $(2004,2007)$ for a detailed analysis of the 


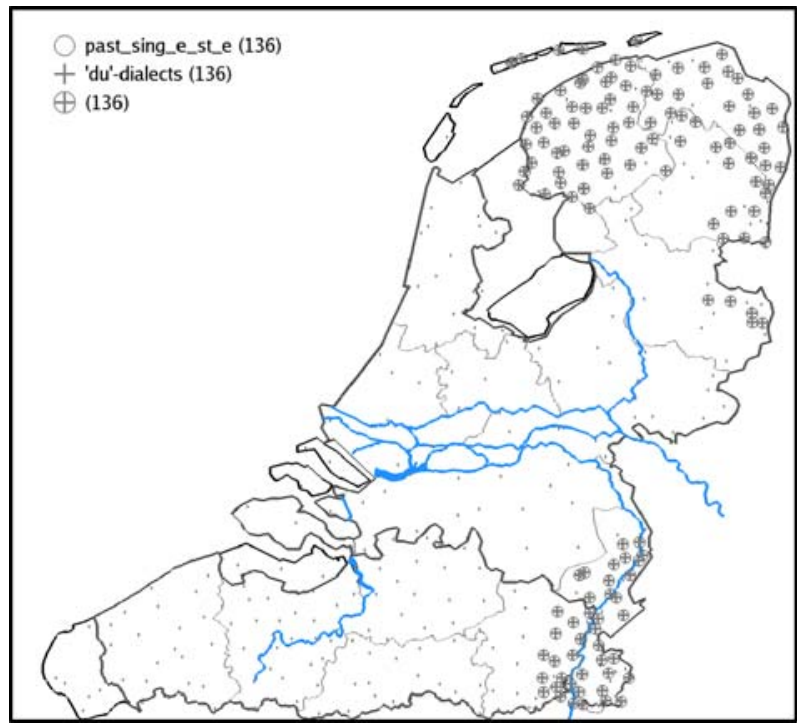

Map 3136 dialects with $d u$ [2nd sing.] and -st in present and past 2nd pers. sing

factors that contributed to the loss of $d u$; here, it suffices to say that there is an independent explanation for the retention of person marking in the singular past tense for this large group of dialects.

A second exception to the impoverishment rule (7b) is a group of 26 dialects that have $-e n$ as a second person marker in the past tense. This ending originally stems from the plural. An example is the dialect of Meppel.

$\begin{array}{lll}1^{\text {st }} & \text { klop-te past tense singular of kloppen 'to knock' (Meppel) } \\ 2^{\text {nd }} & \text { klop-te-n } \\ 3^{\text {rd }} & \text { klop-te }\end{array}$

Dialects that have lost $d u$, have replaced this pronoun (through a strategy of 'politeness') with a second person plural pronoun, and with this pronoun also its inflectional ending. In most cases this yielded $-t$ in second person singular, but in the Northern dialects second person plural combined with -en rather than with $-t$. In these 26 dialects, we still find this originally plural ending -en that entered the paradigm via a politeness strategy in the second person singular (Map 4).

So, it seems that the syncretic pattern is indeed stable across the majority of measure points. We should be careful however in some cases, since the same syncretism may have a different origin. There is a small group of 10 dialects that have three different person markings in the present tense singular (e.g. the dialect of Volendam has klop-kloppe-klopt), having a uniform -e (schwa) in the past tense (singular). Since these dialects have three different person endings in the present singular, we may expect that also in the past tense a separate second person marking is present. So, prima facie the fact that we find the syncretic pattern in these dialects 


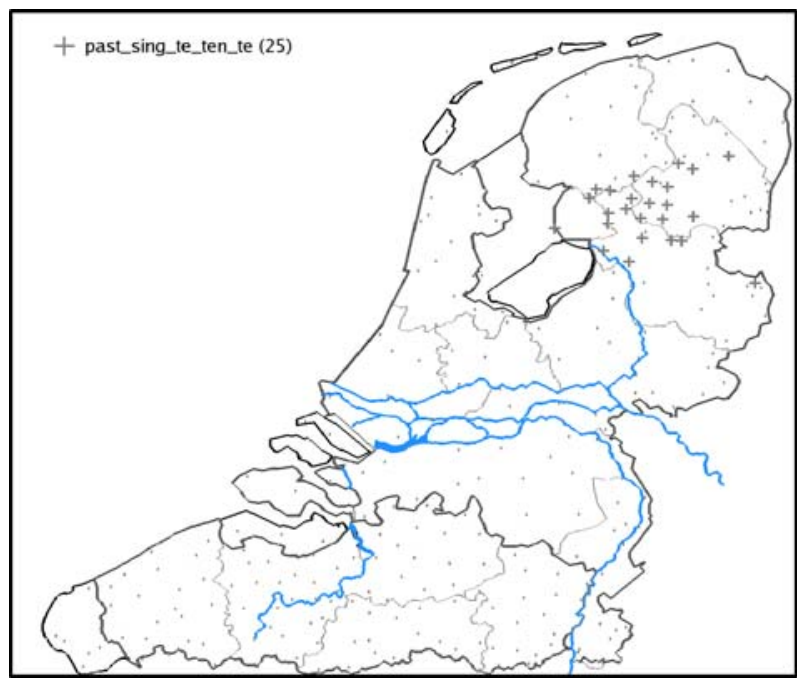

Map 425 dialects with -en in the second person singular past tense

seems convincing evidence for the lack of person marking in the past tense. However, there is a different possible interpretation for this pattern. It may also be the case that underlyingly the past tense affixes are -te, -ten, and -te in 1st, 2nd and 3 rd person respectively, and that deletion of final $-n$, which is widely attested in many Dutch dialects (cf. De Wulf and Taeldeman 2001; de Vogelaer 2005, p. 22) has occurred, rendering a pattern that superficially seems syncretic. In order to test whether we have exaggerated the syncretic patterns in this way, we have looked at the inflectional patterns in irregular verbs in these dialects.

Interestingly, indeed some of these dialects still have second person markings in the past tense (6/10) (ik was 'I was'; jij waarre 'you were', hij was 'he was'), but others have lost the distinction (4/10). In some dialects (e.g. Koedijk) we see both patterns in competition (jij was // jij waarre). In this case it cannot be a consequence of a phonological rule (since that would result in jij waar). Our conclusion is that we see a transition towards the syncretic pattern.

\subsection{Person marking in the past tense plural}

Finally, we turn to the plural marking in the past tense. Only $43(=7 \%)$ of the measure points show person marking in the past tense plural in the verb kloppen. A typical paradigm of this sort is found in the dialect of Waregem:

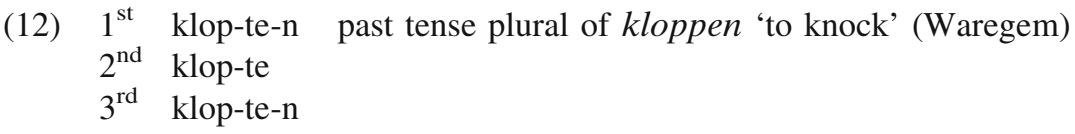

Map 5 gives an idea of the location of these dialects. 


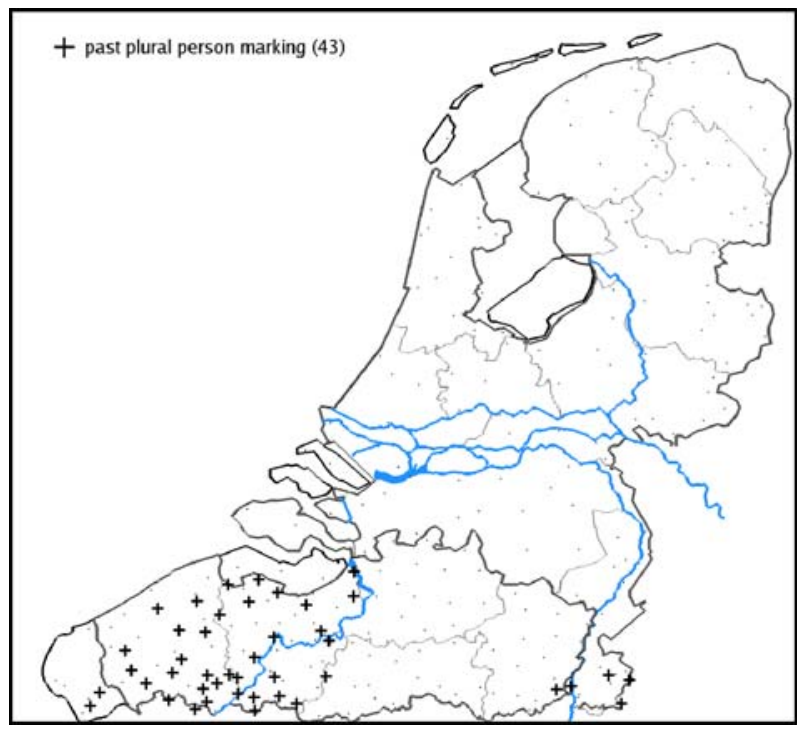

Map 543 dialects with person marking in the past plural

Again, as in the cases above, there are two possible interpretations for the fact that the syncretic pattern is so wide-spread. It may either be the result of the impoverishment rule in (7b) (or a similar paradigmatic force active in the language) or it may result from deletion of the final nasal; the underlying forms of the past tense being -ten, -te, and -ten for 1st, 2nd and 3rd person respectively.

In order to test whether the impoverished patterns can also be explained in this way, we have looked at the inflectional patterns in an irregular verb. In the irregular verbs like breken ('to break') a common pattern in the past plural is brachten, bracht, and brachten for 1st, 2nd and 3rd person. Even if $n$-deletion occurs, second person remains distinctly marked, i.e. it still lacks final schwa. If in the plural of the past tense of the verb breken all forms are syncretic, we may safely conclude that this absence cannot be the result of $n$-deletion. Map 6 shows the measure points where person is marked in the past plural tense in the verb breken.

If we compare the Map 6 with Map 2 we can observe that there is almost a complete overlap between measure points where person is marked in the present tense plural of the verb kloppen and in the past tense plural of the verb breken. Person marking in the plural of the past tense implies that person is also marked in the plural of the present tense. Again, the conclusion is warranted that dialects move towards the impoverished pattern.

\section{Conclusion}

We have investigated the variation in the inflectional patterns of 613 data-points in Dutch dialects. We found that the most stable patterns amidst the rich variation are 


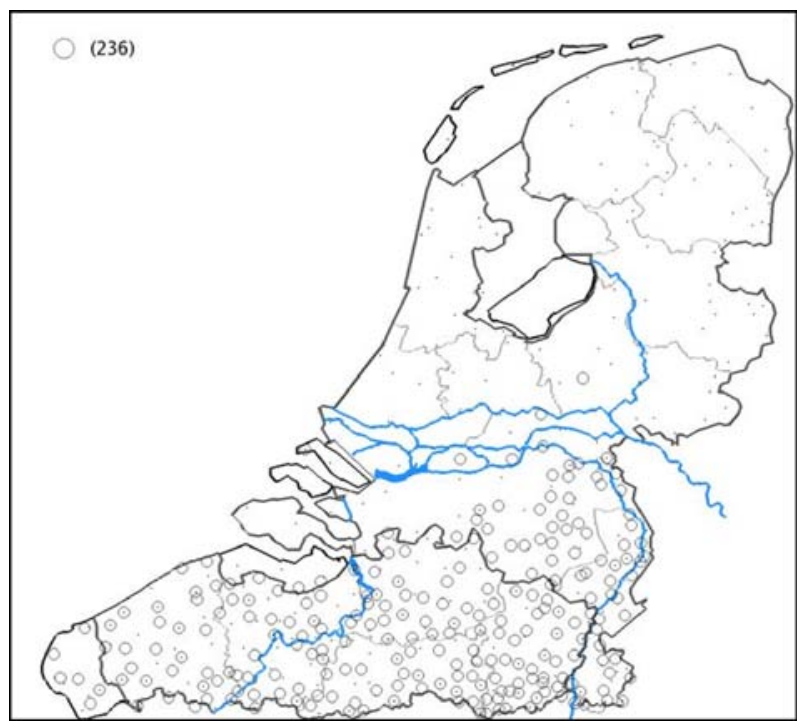

Map 6 Past plural of breken with person marking

of a paradigmatic nature. That is, these patterns cannot be described by merely underspecifying the affixes involved, [as proposed by Bennis and Maclean (2006)] since the same patterns recur in different dialects with different affixes. Therefore, in order to describe the generalizations properly, we need some kind of grammatical mechanism that expresses these patterns directly in terms of the morphosyntactic features involved. Impoverishment rules as proposed within Distributed Morphology are able to do the job, but we believe that other paradigmatic approaches are equally suitable.

It should be pointed out that the paradigmatic patterns are typologically wellattested and that they conform to a general tendency visible in such patterns that neutralization of a morphosyntactic category occurs in the marked half of a paradigm (cf. Bobaljik 2008). Since [plural] is the marked value of the category [number] (cf. Aikhenvald and Dixon 1998, p. 66; Baerman et al. 2005, pp. 59, 200), we expect person distinctions to be neutralized in the plural. If person distinctions also happen to be absent in the singular, they should also be absent in the plural. Similarly, since [past] is marked with respect to [present] (Greenberg 1966, p. 48, de Hoop et al. 2004), we expect neutralizations to occur in the past tense. This is exactly what we find in the Dutch dialects. There are no dialects that lack person distinctions in the unmarked half of the paradigm (singular or present tense) having person distinctions in the marked half of the paradigm.

However, at the same time the neutralization patterns are not without exceptions. That is, in some dialects, neutralization of person distinctions in the past and plural does not occur. These dialects show retention of forms from an older stage of the language. Further research should show why particularly those dialects retain these older richer paradigms, where they are lost in so many others. 
Acknowledgements We thank the audience at MMM6, Ithaca, for comments and discussion. We also thank Fred Weerman for comments on an earlier version; and Alies MacLean and Olaf Koeneman for interesting and fruitful discussions.

Open Access This article is distributed under the terms of the Creative Commons Attribution Noncommercial License which permits any noncommercial use, distribution, and reproduction in any medium, provided the original author(s) and source are credited.

\section{References}

Aalberse, S. P. (2004). Waer bestu bleven? De verdwijning van het pronomen 'du' in een taalvergelijkend perspectief. Nederlandse Taalkunde, 9(3), 231-252.

Aalberse, S. P. (2007). The typology of syncretisms and the status of feature structure. Verbal paradigms across 355 Dutch dialects. Morphology, 17(1), 109-149.

Aikhenvald, A. Y., \& Dixon, R. M. W. (1998). Dependencies between Grammatical Systems. Language, $74(1), 56-80$.

Baerman, M. (2000). Contrary to syncretic structure. Presentation LAGB.

Baerman, M., Brown, D., \& Corbett, G. (2005). The syntax-morphology interface: A study of syncretism. Cambridge: Cambridge University Press.

Barbiers, S., et al. (2006). Dynamische Syntactische Atlas van de Nederlandse Dialecten. Amsterdam: Meertens Instituut. http://www.meertens.knaw.nl/sand/.

Bennis, H., \& MacLean, A. (2006). Variation in verbal inflection in Dutch dialects. Morphology, 16(2), 291-312.

Bobaljik, J. D. (2003). Syncretism without paradigms: Remarks on Williams 1981, 1994. In G. E. Booij \& J. van Marle (Eds.), Yearbook of morphology 2002 (pp. 53-85). Dordrecht: Kluwer.

Bobaljik, J. D. (2008). Missing persons: A case study in morphological universals. The Linguistic Review, 25(1-2), 203-230.

Booij, G. E. (2002). The morphology of Dutch. Oxford: Oxford University Press.

Cysouw, M. (2005). What it means to be rare: The variability of person marking. In Z. Frajzyngier, A. Hodges, \& D. S. Rood (Eds.), Linguistic diversity and language theories (pp. 235-258). Amsterdam, Philadelphia: John Benjamins.

de Hoop, H., Haverkort, M., \& van den Noort, M. (2004). Variation in form versus variation in meaning. Lingua, 114(9-10), 1071-1089.

de Vogelaer, G. (2005). Persoonsmarkering in de dialecten van het Nederlands en het Fries. http:// users.ugent.be/ gdvogela/proefschrift.

De Wulf, C., \& Taeldeman, J. (2001). Apocope en insertie van -n na sjwa in de zuidelijk Nederlandse dialecten: conditionering en geografie. In L. Draye, H. Ryckeboer, \& J. Stroop (Eds.), De Variabiliteit van de $-e(n)$ in het Nederlands (Taal \& Tongval themanummer 14) (pp. 7-51). Gent: Koninklijke Academie voor Nederlande taal- en letterkunde.

Greenberg, J. H. (1966). Language universals with special reference to feature hierarchies. The Hague, Paris: Mouton.

Halle, M. (1997). Distributed morphology: Impoverishment and fission. In MIT Working Papers in Linguistics (Vol. 30, pp. 425-449).

Halle, M., \& Marantz, A. (1993). Distributed morphology and the pieces of inflection. In K. Hale \& S. J. Keyser (Eds.), The view from building 20, essays in linguistics in honor of sylvain bromberger (pp. 111-176). Cambridge, Massachusetts: MIT Press.

Stump, G. T. (2001). Inflectional morphology: A theory of paradigm structure. Cambridge: Cambridge University Press.

van den Berg, B. L. (2003). Phonology \& morphology of Dutch \& Frisian. Dialects in 1.1 million transcriptions. Goeman-Taeldeman-Van Reenen project 1980-1995 (CD_ROM). Amsterdam: Meertens Instituut.

Williams, E. (1994). Remarks on lexical knowledge. Lingua, 92(1), 7-34.

Wunderlich, D. (1997). A minimalist model of inflectional morphology. In C. Wilder, H. M. Gärtner, \& M. Bierwisch (Eds.), The role of economy principles in linguistic theory (pp. 267-298). Berlin: Akademie Verlag. 